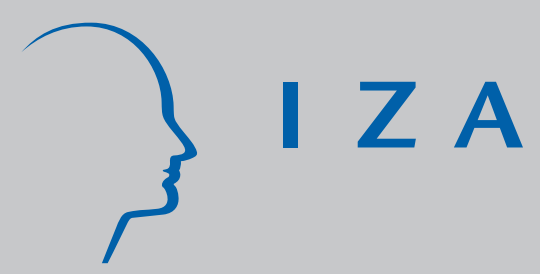

IZA DP No. 404

Human Capital Spill-Overs Within the Workplace

Harminder Battu

Clive R. Belfield

Peter J. Sloane

November 2001 


\title{
Human Capital Spill-Overs Within the Workplace
}

\author{
Harminder Battu \\ Department of Economics, University of Aberdeen \\ Clive R. Belfield \\ National Center for the Study of Privatization in Education, \\ Teachers College, Columbia University \\ Peter J. Sloane \\ Department of Economics, University of Aberdeen and IZA, Bonn
}

\author{
Discussion Paper No. 404 \\ November 2001
}

\author{
IZA \\ P.O. Box 7240 \\ D-53072 Bonn \\ Germany \\ Tel.: +49-228-3894-0 \\ Fax: +49-228-3894-210 \\ Email: iza@iza.org
}

This Discussion Paper is issued within the framework of IZA's research area Mobility and Flexibility of Labor Markets. Any opinions expressed here are those of the author(s) and not those of the institute. Research disseminated by IZA may include views on policy, but the institute itself takes no institutional policy positions.

The Institute for the Study of Labor (IZA) in Bonn is a local and virtual international research center and a place of communication between science, politics and business. IZA is an independent, nonprofit limited liability company (Gesellschaft mit beschränkter Haftung) supported by the Deutsche Post AG. The center is associated with the University of Bonn and offers a stimulating research environment through its research networks, research support, and visitors and doctoral programs. IZA engages in (i) original and internationally competitive research in all fields of labor economics, (ii) development of policy concepts, and (iii) dissemination of research results and concepts to the interested public. The current research program deals with (1) mobility and flexibility of labor markets, (2) internationalization of labor markets and European integration, (3) the welfare state and labor markets, (4) labor markets in transition, (5) the future of work, (6) project evaluation and (7) general labor economics.

IZA Discussion Papers often represent preliminary work and are circulated to encourage discussion. Citation of such a paper should account for its provisional character. 
IZA Discussion Paper No. 404

November 2001

\section{ABSTRACT}

\section{Human Capital Spill-Overs Within the Workplace}

An individual's human capital has a strong influence on earnings. Yet individual, worker-level estimations of earnings rarely include the characteristics of co-workers or detailed firm-level controls. In this paper, we use a unique matched worker-workplace dataset to estimate the effect on own earnings of co-workers' education. Our results, using the 1998 UK Workplace Employee Relations Survey, show significant effects. Own earnings premia fall slightly, but there is an independent, significantly positive effect from average workplace education. We also test for interactions between own and co-worker education levels. However, these interactions appear negative: education is valued less highly at workplaces where education levels are already high. This result runs counter to our theoretical prediction.

JEL Classification: I2, J4

Keywords: Educational economics, human capital, workplace performance

Peter J. Sloane

Department of Economics

University of Aberdeen

AB24 3QY

Scotland

Tel.: +44 (0)1224 272080

Fax: +44 (0)1224 272082

Email: pec063@abdn.ac.uk 


\section{Introduction}

The education earnings relationship is one of the most intensively tested in economics (Lazear, 2000) and there is substantial evidence that an individual workers' productivity and wages depend in large part on their human capital. There is also a sizeable literature on social externalities from education, i.e. spillover benefits from educated individuals to others (Wolfe and Zuvekas, 2000). However, there is surprisingly little evidence on whether these spillover effects obtain within the workplace, and what effect these might have on own earnings. In particular, there is no clear indication as to whether educated co-workers raise or lower own earnings.

There are a number of potential avenues through which co-workers' human capital will influence own wages: Idson and Kahane (2000) refer to a team dynamic, but equally strong effects may emerge from information-sharing, from skill complementarity and from training by co-workers (Barron et al., 1997), or from more 'rational' behaviour (Behrman and Stacey, 1997). It seems likely that co-workers will trade these human capital skills, to mutually raise productivity. However, there are two potential reasons as to why coworkers' human capital need not be complementary to own human capital. First, if coworkers have different amounts of human capital, then there may be a 'skills incompatibility' (Kremer, 1993): a firm with a uniform standard of education may have higher productivity. Second, if workers are in competition with each other for high-paying jobs within the firm, they may engage in activities to undermine their competitors and promote themselves 
(Winter-Ebmer and Zweimuller, 1997). ${ }^{1}$ Thus, both the amounts and the distribution of workplace human capital are likely to influence earnings, and the directions of these influences can only be assessed empirically.

This paper tests these human capital interactions directly, using random samples of workers from UK workplaces. The paper is structured as follows. In Section 2, the possible externalities from co-worker human capital are discussed, along with the pertinent (but mainly indirect) evidence; this discussion allows for formulation of testable hypotheses about the effects on earnings. In Section 3 we describe the dataset used: the UK Workplace Employee Relations Survey (1998). In Section 4, the effects of workplace education on own earnings are tested. In Section 5, a summary and conclusion is offered.

\section{Theory and Evidence on Human Capital Spillovers}

\subsection{Returns to Human Capital Within the Workplace}

The literature on the earnings premia from education is vast (see recent reviews by Ashenfelter et al., 2000; Ashenfelter and Rouse, 2000; Cohn and Addison, 2000). Broadly, this cross-sectional, correlational literature indicates that in Western economies the wage premium for each additional year of education is approximately $5-10 \%$ (for the UK, see Blundell et al., 2000). Moreover, this premium is not substantially altered when the endogenous decision to become educated is modelled (e.g., from twins studies or natural experiments, Miller et al., 1997; Harmon and Walker, 1995). The impact of own education

\footnotetext{
${ }^{1}$ Negative effects may also arise if a sizeable proportion of the workforce has more education than is required for their job: they are over-educated (Oosterbeek, 2000). It is well documented that overeducation generates a wage penalty relative to being fully matched.
} 
on own productivity and earnings is strong and robust. In addition, workers' productivity may also depend on the education of co-workers within the firm. Workers do not always work autonomously. Many tasks require group work, with skills diffused through teams and across the workplace; and organisational cultures (e.g. those associated with high-performance management) may depend on the average workforce skill level. Furthermore, firms may deliberately cultivate a team dynamic, with information-sharing, cotraining, monitoring, and support so as to exploit these spillovers. Idson (1995), for example, looks at how earnings are correlated with production in teams, as well as with behavioural traits such as team size, encouragement and helpfulness.

The notion of human capital spillovers gains support from the substantial literature on the societal externalities from education (Wolfe and Zuvekas, 2000; Taylor, 2000). In fact, enterprises may even be able to generate more externalities than exist in societies, insofar as they can enforce tighter contracts across workers. The possibility of positive spillovers is at least indirectly suggested by evidence such as the positive clustering of high-skilled professionals with high-skilled non-professionals in the US (Bronars and Famulari, 1997), the positive earnings effect from increasing proportions of skilled workers in a firm (Troske, 1999), and from sports performances, where team dynamics clearly occur (Idson and Kahane, 2000). ${ }^{2}$ As well, there is a positive correlation between all individuals' earnings and the average education level of a region (Rauch, 1993), and a 'brain drain' of educated workers to areas where there are other educated workers (Borjas et al., 1992). ${ }^{3}$ Human

\footnotetext{
2 Macro-economic models and endogenous growth models draw on the notion of 'production externalities', with economic growth boosted through more efficient social capital investments (McMahon, 2000; Romer, 1994).

${ }^{3}$ In an unpublished study, Barth (2000) directly tests the effects on co-worker earnings using two types of matched employer-employee data from Norway: an independent effect on own pay from the average level of education within an establishment ranges from $1 \%$ to $4 \%$ per year of average education. In
} 
capital spillover effects may therefore exist: working with others who have high education levels may independently raise own earnings (and this may explain some of the observed firm-level heterogeneity in earnings, see Bayard and Troske, 1999; Abowd et al., 1999).

However, own earnings may be affected by the dispersion of human capital within the workplace. This line of argument may run counter to the notion of externalities. In Kremer's (1993) oring theory, for example, the productivity of high-skilled workers is increasing in the skill levels of co-workers. The o-ring theory predicts that an important determinant of factor payments is the compatibility of standards: where workers are of a 'compatible standard', they will earn more. Perhaps training programs are easier to implement (Barron et al., 1997; van Smoorenberg and van der Velden, 2000), or there are fewer co-ordination failures in standardised workplaces. In this theory, an increase in education levels within the workplace may not raise earnings if it also serves to widen the dispersion of education levels; but earnings will be raised where high-skilled workers cluster together.

More generally, there is a sizeable literature that indicates that many workers do not have the optimal amount of education for their jobs (see the review in Oosterbeek, 2000). For the UK, over-education is significant and substantive, years of surplus education only weakly affect individual earnings, and they negatively affect job satisfaction (Battu et al., 1999; Dolton and Vignoles, 2000). The point is that if workers have accumulated more education than is optimal, any externalities may be subverted: for an individual worker, overeducation may mean reduced productivity, earnings and job satisfaction, while at the same

contrast, Groshen (1991) finds that education levels very weakly reduce establishment wage 
time that worker may distract or demoralise other workers. Monitoring costs for the firm may be pushed up, to avoid workers who adroitly perform the set tasks distracting coworkers. ${ }^{4}$ So although co-workers' years of education may boost earnings, if these are surplus years of education they may impair own earnings. ${ }^{5}$

A third reason to doubt a positive effect from co-worker human capital is the possibility of intra-firm job tournaments. Where workers with equivalent skills compete for promotions, they may sabotage each other, and so reduce productivity overall. Finally, spillover effects may not be appropriated by workers, but instead by managers in terms of higher profits. Although possible, this last effect seems unlikely since highly educated workers would probably be the most effective at bargaining for higher shares of the workplace surplus.

There are plausible arguments on both sides, regarding the complementarity of human capital within a workplace. Ultimately, the net effect can only be decided empirically. In addition, such empirical research may have implications for assessing the benefits of education. If human capital spillover effects are important, and there is clustering of education levels within workplaces, this may influence how the earnings premium to education is interpreted. The earnings premium is typically attributed to human capital and not to labor market sorting, i.e. where workers are hired according to their credentials (see the discussion by Belfield, 2000). Yet, part of this premium may be a consequence of

\footnotetext{
differentials.

${ }^{4}$ Yet, across the workplace, over-education may be minimal: either the employee mix could be adjusted so that over-educated and under-educated workers compensate for each other, or physical capital intensities may be varied. However, over-educated workers may guide or assist co-workers who only have the required education and it may be under-educated workers who are less competent, need greater monitoring or require more co-worker support (Tsang et al., 1993).

5 Tsang (1987), with data from the Bell Company, finds over-education reduces firm output via a negative effect on job satisfaction. Other indirect evidence of the effect of the human capital mix on firm
} 
educated workers being hired to workplaces where the average education level is high. These workers then 'share' their human capital and so have higher earnings. Education still enhances productivity and so earnings, but part of that enhancement comes from education's role in securing for a given worker a job which allows for interaction with other skilled workers.

\subsection{Model Specification}

The above arguments can be modelled formally. An appropriate specification of the relationship between own earnings and co-worker attributes is laid out by Idson and Kahane (2000):

$$
\ln y_{i j}=a_{1}+a_{2} e_{i j}+a_{3} E_{j}+a_{4} e_{i j} * E_{j}+a_{5} z_{i j}+a_{6} Z_{j}+v_{j}+u_{i}
$$

In equation (1), own individual earnings $y_{i j}$ are determined by: the education $e_{i j}$ of individual $i$ at workplace $j$; the education levels of co-workers $E_{j}$; and the interaction between these two education levels. A vector of worker and workplace controls $\boldsymbol{z}_{i j}$ and $\boldsymbol{Z}_{j}$ are also included $\left(v_{j} \sim \mathrm{N}\left(0, \sigma_{\mathrm{j}}\right)\right.$ and $u_{i} \sim \mathrm{N}\left(0, \sigma_{\mathrm{i}}\right)$ are iid workplace and individual error terms). Under this specification, an additional year of an individual worker's own education affects their earnings by $\mathrm{a}_{2}+\mathrm{a}_{4} E_{j}$. The coefficient $\mathrm{a}_{2}$ captures the direct effect of years of education, and the coefficient $a_{4}$ captures the effect of average co-worker education on how own education is valued. An additional cross-workplace increase in education of one year will increase own earnings by $\mathrm{a}_{3}+\mathrm{a}_{4} e_{i j}$. Co-worker education will impact directly through the coefficient estimated as $\mathrm{a}_{3}$, and indirectly through the interaction coefficient $\mathrm{a}_{4}$. Here, if $\mathrm{a}_{3}$ is 
non-zero, then its omission (or that of $\mathrm{a}_{4}$ ) serves to bias upwards $\mathrm{a}_{2}$, the standard measure of the education premium. The expectation is that $a_{3}$ and $a_{4}$ will be positive, although only limited evidence is so far available on each of these coefficients. Where $a_{3}$ is positive, own earnings are positively related to co-workers' education; where $\mathrm{a}_{4}$ is positive, increased years of co-worker education raise wages for those with high education levels.

The sign of coefficient a $a_{4}$ offers one test of Kremer's hypothesis about compatible standards of inputs, but further tests are also possible. One simple test is to include the absolute mean dispersion of education levels $E_{j}$ on the right hand side of equation (1). To capture non linear effects we can also include the square of workplace human capital $E_{j}^{2}$. Both these tests are included below.

In summary, the following hypotheses are offered. First, own education raises earnings. Second, workplace education levels raise own earnings. Third, the dispersion of workplace education levels lowers earnings. It is possible to test these hypotheses using matched worker-workplace data.

\section{Data and Measures}

To test these hypotheses, the dataset used is the Workplace Employee Relations Survey (WERS), collected in 1998 (DTI, 1999). The WERS is a national sample of interviews with managers from 2,191 UK establishments with at least ten workers. The firm-level survey addresses the 'management of employees', with information on workforce 
composition and workplace performance (see Cully et al., 2000). In addtion, 25 employees at each workplace were randomly selected for individual survey. This survey asked questions about individuals' education, pay and job satisfaction, as well as a range of personal characteristics. The information set is therefore rich, with detailed information on multiple workers per workplaces. For estimation, the sample here is restricted to full-time workers and to workplaces where more than three workers responded to the worker survey. This yields information on 18,304 workers across 1,389 workplaces.

The derivation of the key variables is briefly described here: a full derivation is reported in Appendix Table 1, along with a catalogue of substitute derivations of the key variables. The simplest way to estimate these relationships is to use years of education as the unit of account. First, each workers' years of education were calculated, to obtain $e_{i}$; these calculations were based on qualifications, and so full sensitivity analysis is conducted below. Second, workplace education levels $E_{j}$ were derived using both worker and workplace data. Based on the full worker sample, mean years of education per occupation are calculated. This mean can then be weighted for each workplace, using information on the occupational mix of the entire workforce at each workplace. (Two alternative measures of mean workplace education are available, and these are utilized in the sensitivity testing). Third, the dispersion of workplace education levels $E_{j}$ is also calculated: this dispersion measure is the average of absolute differences between own education and mean workplace education. Fourth, pay levels $y_{i j}$ are taken from self-reports across 12 wage bands, and converted into earnings per hour using the reports of hours worked. Median pay across the workplace $Y_{j}$ is also available; this variable is based on the distribution of pay across the workforce, as reported by the manager. 
Basic frequencies for the key variables are reported in Table 1 (with full frequencies for the other variables detailed in Appendix Table 2). The average years of education per male (female) worker are 13.67 (13.76). Mean education levels per workplace are 13.45 (s.d., 1.20), so the sample of respondents has slightly more education than the average of their workplace. The dispersion of education across a workplace is 2.21 (s.d., 0.64). For the dependent variables, log pay per hour per individual worker is 1.94; and log median earnings per workplace are 9.55.

Such matched worker-workplace data is ideal for testing the hypotheses listed above. There are detailed controls for each worker, workplace information from two sources (the manager and the worker respondents), and full information on education, pay, and job satisfaction. This allows for numerous sensitivity tests and cross-validation of the results. One potential caveat is that this analysis relates to workplaces rather than teams: co-worker, in this sense, refers to those in the same workplace, rather than those doing the same tasks or team-working. (No ability controls are available, either). Nevertheless, the random sample of workers and the detailed information on both workers and workplaces essential for investigating these arguments - is unique for the UK economy.

\section{Estimation and Results}

\subsection{The Effects of Workplace Education on Own Earnings}

The main hypothesis is whether earnings are increasing in the education levels of coworkers. Table 2 reports a series of Mincerian earnings equations, estimated with both own 
and co-worker levels of education against log pay per hour. As per equation (1), which includes error terms for workplaces and individuals, Random Effects Generalized Least Squares is used. ${ }^{6}$ Model [1] includes individual characteristics $z_{i}$ only (detailed in the notes to Table 2); it shows the earnings premium for an additional year of education is $6.0 \%$ (6.4\%) for males (females). Approximately $40 \%$ of the variation in earnings is explained; and the fraction of the variance attributable to the workplace error term $?_{j}$ is 0.3710 (0.3496). By introducing firm-level characteristics $\boldsymbol{Z}$ as per Model [2], the premium to education falls slightly, with an increase in the explained variation to $47 \%(46 \%)$; and the workplace error term variance falls, so $?_{j}$ is now $0.2833(0.2437)$.

Model [3] includes the average years of education across the workplace $E_{j}$ as an additional firm-level variable. This variable is statistically significant and has a substantive effect on own earnings: an across-the-workplace increase in education of 1.2 years (one standard deviation) raises own earnings by $13.0 \%$ (8.9\%). The premium to own education is reduced, although again not substantially. The strength of the coefficient $\left(a_{3}>0\right)$ suggests that own and co-worker education appear to be strongly complementary. In substantive terms, it is important to note that an increase of one standard deviation must be applied across all the workforce, and the average workforce size is 45 . Based on the premium to education, for an enterprise which raises workplace education levels by one standard deviation then the total wage bill would be approximately $7 \%$ higher.

Model [4] is the full estimation specified as equation (1), to include the interaction between own and co-worker years of education (Idson and Kahane, 2000). This

\footnotetext{
${ }^{6}$ Random effects GLS is a less biased estimator than OLS, because the data are grouped across workplaces (Moulton, 1987). A Hausman test easily rejects the use of OLS $\left(?^{2}=99.88\right)$. Using OLS, the coefficient on $\mathrm{e}_{\mathrm{ij}}$ for Model [1] is 0.0785 (0.0732) for males (females).
} 
interaction term has a negative sign for males and is statistically significant at $1 \%$ level (no effect is identifiable for females). Own education appears to be rewarded at a relatively lower rate in firms where education levels are already high. This result $\left(\mathrm{a}_{4}<0\right)$ runs directly counter to the predictions of Idson and Kahane (2000) and Kremer (1993). However, these relationships can be tested further.

The effect of the spread of human capital is reported in Table 3. Two tests are applied. First, a direct measure of dispersion $E_{j}$ is included in Model [4] in place of the interaction term. The upper panel of Table 3 shows that, adjusting for overall workforce human capital, greater dispersion of education across the workplace is associated with higher own earnings: a one standard deviation increase in dispersion raises own earnings by $2.3 \%(3.3 \%)$. Second, the square of workplace years of education is reported in the bottom panel of Table 3. The coefficients on workplace education are positive, but for its square they are negative: workplace education boosts own earnings, but at a declining rate. Both these tests suggest against the hypothesis of increasing returns to skill in standardised workplaces.

Finally here, the effects are tested across union and non-union workers. This split is interesting, because the results could go either way. Unions may facilitate the sharing of skills across workers, who then collectively bargain over pay. With facilitation, the probability of invidious competition between workers would be lower and so crossworkplace spillovers of human capital should be stronger. Yet, if unions instead demarcate skills and apportion tasks, this would reduce the opportunities for human capital spillovers. Models [3] and [4] are reported in Table 4. These estimations show that both the returns to own education and to co-worker education are lower amongst union members. Moreover, 
the interaction term $e_{i j}{ }^{*} E_{j}$ is strongly significant and negative for male non-union workers, but not for union workers (yet, for female non-union workers it is positive; for union workers it is negative). These results suggest that unions - by reducing the returns to education - play a demarcational role, rather than a skill-sharing one.

\subsection{The Effects of Workplace Education on Own Earnings: Sensitivity Tests}

A series of tests for the robustness of the results in Table 2 were undertaken. The sensitivity tests were grouped in three categories: (i) restrictions on the sample for estimation; (ii) respecification of the data; and (iii) use of alternative derivations of $e_{\mathrm{i}}, E_{j}$ and $y_{i j}$.

Table 5 reports estimations of Models [3] and [4], but with sample restrictions applied. The sample is restricted to those workplaces where it might plausibly be expected that human capital spillovers would be the strongest, i.e. those workplaces where there is high team-working and or where the technology is labor-intensive. ${ }^{7}$ Reducing the sample inflates the standard errors, and this generates some sensitivity across the results. First, the sample is restricted to firms where at least $60 \%$ of workers are reported to work in teams, on the assumption that human capital spillovers will be strongest in workplaces where teamworking is prevalent. Panel 1 of Table 5 shows that the coefficient for $E_{j}$ remains statistically significant, as does the interaction term $e_{i} * E_{j}$ for male workers. Second, the sample is only of workers in labor intensive firms, i.e. where labor accounts for more than $75 \%$ of operating costs. In panel 2 of Table 5, average years of education remain significant, but here the interaction term falls to insignificance.

\footnotetext{
${ }^{7}$ Small firms may also rely more on human capital spillovers. When only firms of less than 40 workers are included, however, the interaction terms are all insignificant.
} 
As a second set of checks, a series of further specification tests were undertaken. These tests included: OLS estimation for each specification; inclusion of occupational dummy variables for each individual; pooling the genders; and application of the survey weights for the data. In most cases, the results were unaffected; in some cases, the negative effect was strengthened and in only instance (male union sample, occupational dummies included) was a positive and statistically significant coefficient obtained for the interaction term $e_{\mathrm{i}}^{*} E_{j}$.

The third set of sensitivity tests related to alternative derivations of the key dependent and independent variables $e_{i}, E_{j}$ and $y_{i j}$. First, workplace education levels $E_{j}$ were re-calculated using occupational averages from the 1998 UK Labour Force Survey and using the actual average of the workers' responses. These are described as $E 2_{j}$ and $E 3_{j}$ in the Appendix. Second, the dispersion measure was calculated using squared dispersions rather than absolute dispersions (see Appendix Table 1). Finally, interval regression was applied to the $\log$ of annual earnings values $y 2_{i j}$, instead of $\log$ pay per hour $y_{i j}{ }^{8}$ Across this set of tests, the coefficients represented in Tables 2-5 were unaffected.

\subsection{The Effects of Workplace Education on Median Workplace Wages}

A final relevant estimation is available using the WERS. This draws on the workplace level reports of the log median wage across each firm $Y_{j}$ (see the Appendix for calculation). As with earlier estimations of Model [3], column 1 of Table 6 shows the strongly positive effect of the average education level on the median wage of the establishment. Increasing the

\footnotetext{
${ }^{8}$ The interval regression yielded no differences in the results, compared to those reported in the main text. Hourly pay is used here, as a better measure of productivity, than the annual pay intervals. Hourly pay is not fully in intervals, because individuals reported the exact number of hours worked; so interval
} 
average workforce education by 1.2 years, this raises the median workplace wage by $15.6 \%$, similar to the estimate of $13.0-8.9 \%$ reported in Table 2, given that the latter controls directly for own education. Column 2 shows the effect of the dispersion of education: a one standard deviation increase in dispersion raises median earnings by $1.4 \%$. Again, these results are not sensitive to the weighting procedure or more parsimonious modelling.

\section{Conclusion}

For the first time using British data this paper investigates the possibility that there are spillover effects of education within the workplace. Spillover effects are found to positively influence own earnings, and these effects are largely independent of the effect from own education. However, the hypothesis that co-worker education is most beneficial when it is accompanied by a uniform standard of education (the o-ring theory) was also tested. One prediction - that the benefits of education are increasing in own education levels - is rejected using three separate tests. Although the significance of this result is not consistently maintained during sensitivity analysis, there is no evidence to support the hypothesis.

The main result is nonetheless particularly important: workplace education levels have a strong effect on own earnings, only slightly reducing the premium to own education. It does appear, however, that the earlier human capital literature may have underplayed the external effects of education on economic outcomes, particularly for workers themselves. If 
education sorts workers into high productivity firms, this is still a 'benefit' from education - whether it is clearly a human capital benefit remains to be identified. Moreover, we find that own education is relatively less well-rewarded in workplaces which already have high education levels. This result conflicts with our expectations, and perhaps indicates stronger competitive pressures amongst educated co-workers.

authors. 


\section{Acknowledgements}

An earlier version of this paper was presented at the LXXII'th International Conference of the Applied Econometrics Association, Economics and Human Resource Management, Helsinki, 22-23 ${ }^{\text {rd }}$ September 2000. The authors are grateful to the participants for helpful comments.

The authors acknowledge the Deparment of Trade and Industry, the Economic and Social Research Council, the Advisory, Conciliation and Arbitration Service and the Policy Studies Institute as the originators of the 1998 Workplace Employee Relations Survey data, and the Data Archive at the University of Essex as the distributor of the data. None of these organisations bears any responsibility for the authors' analysis and interpretations of the data.

\section{References}

Abowd, JM, Kramarz, F and DN Margolis. 1999. High wage workers and high wage firms. Econometrica, 67, 251-333.

Ashenfelter, O, Harmon, C and H Oosterbeek. 2000. A review of estimates of the schooling/earnings relationship, with tests for publication bias. Labour Economics, 6 , 453-470.

Barron, JM, Berger MC and DA Black. 1997. How well do we measure training? Journal of Labor Economics, 15, 507-528.

Barth, E. 2000. External effects of education? Evidence from the wage structure. Institute for Social Research, Oslo.

Battu, H, Belfield, CR and P Sloane. 1999. Over-education among graduates: a cohort view. Education Economics, 7, 21-38.

Battu, H, Belfield, CR and P Sloane. 2000. Over-education: how sensitive are the measures?. National Institute Economic Review, 171, 82-93.

Bayard, K and KR Troske. 1999. Examining the employer-size wage premium in manufacturing, retail trade and service industries using employer-employee matched data. American Economic Review, 89,2, 99-103.

Behrman JR and N Stacey. 1997. The Social Benefits of Education. Michigan UP: Michigan.

Belfield, CR. 2000. Economic Principles for Education. Theory and Evidence. Edward Elgar: Cheltenham, UK.

Blundell, R, Dearden L and H Goodman. 2000. The returns to higher education in Britain: evidence for a British cohort. Economic Journal, 110, f82-99.

Borjas, GJ, Bronars SG and SJ Trejo. 1992. Assimilation and earnings of young internal migrants. Review of Economics and Statistics, 74, 170-175.

Borghans, L and A de Grip (eds). 2000. The Over-educated Worker? The Economics of Skill Utilisation. Edward Elgar: Cheltenham.

Bronars, SG and M Famulari. 1997. Wage, tenure, and wage growth variation within and across establishments. Journal of Labor Economics 15, 2, 285-317. 
Clark, A. 1996. Job satisfaction in Britain. British Journal of Industrial Relations, 34, 189-217.

Cohn, E and JT Addison. 1998. The economic returns to lifelong learning. Education Economics, 6, 309-346.

Dearden, L. 1998. The effects of families and ability on men's education and earnings in Britain. Labour Economics, 6, 551-568.

Department of Trade and Industry (DTI). 1999. Workplace Employee Relations Survey: Cross-section 1998. [computer file] $4^{\text {th }}$ Edition: The Data Archive [distributor], 22 December 1999. SN: 3955.

Dolton, PJ and A Vignoles. 2000. The incidence and effects of over-education in the U.K. graduate labour Market. Economics of Education Review, 19, 179-198.

Groot, W and H Maassen van den Brink. 2000. Over-education in the labor market: a meta-analysis. Economics of Education Review, 19,149-159.

Groshen, EL. 1991. Sources of intra-industry wage dispersion: how much do employers matter? Quarterly Journal of Economics, 105, 869-884.

Harmon, C and I Walker. 1995. Estimates of the economic return to schooling for the United Kingdom. American Economic Review, 85, 1278-1286.

Hartog, J and H Oosterbeek. 1998. Health, wealth and happiness: why pursue a Higher Education? Economics of Education Review, 17, 245-256.

Idson, TL. 1995. Team production effects on earnings. Economics Letters 49, 197-203.

Idson, TL and LH Kahane. 2000. Team effects on compensation: an application to salary determination in the National Hockey League. Economic Inquiry, 38, 345-357.

Kremer, M. 1993. The oring theory of economic development. Quarterly Journal of Economics, 107, 551-575.

Lazear, EP. 2000. Economic imperialism. Quarterly Journal of Economics, CXV, 99146.

Machin, A and MB Stewart. 1996. Trade unions and financial performance. Oxford Economic Papers, 48, 213-241.

McMahon, WW. 2000. Education and Development. Oxford University Press: Oxford.

Miller, P, Mulvey, C and N Martin. 1997. Family characteristics and the returns to schooling: evidence on gender differences from a sample of Australian twins. Economica, 64, 119-136.

Oosterbeek, H. 2000. Editorial: the economics of over- and under-schooling. Economics of Education Review, 19,129-131.

Rauch, GE. 1993. Productivity gains from geographic concentration of human capital: evidence from the cities', Journal of Urban Economics, 34, 380-400.

Romer, PM. 1994. The origins of endogenous growth. Journal of Economic Perspectives, 8, 3-22.

Troske, KR. 1999. Evidence on the employer size-wage premium from workerestablishment matched data. Review of Economics and Statistics, 81, 15-26.

Tsang, MC, Rumberger, RW and HM Levin. 1993. The impact of surplus schooling on workers productivity. Industrial Relations, 30, 209-228.

Tsang, MC. 1987. The impact of underutilization of education on productivity: a case study of the u.s. bell companies. Economics of Education Review, 6, 239-54.

Van Smoorenberg, MSM and RKW van der Velden. 2000. The training of school-leavers: complementarity or substitutability? Economics of Education Review, 19, 207-218. 
Winter-Ebmer, R and J Zweimueller. 1997. Unequal assignment and promotion in job ladders. Journal of Labor Economics, 15, 43-71. 
Table 1

Frequencies: Education and Outcome Variables

\begin{tabular}{llll}
\hline \hline Education and Outcome Variables & Code & Mean & $\begin{array}{l}\text { Standard } \\
\text { deviation }\end{array}$
\end{tabular}

Education Variables:

Years of education per worker: male

$\begin{array}{crr}\mathrm{e}_{i j m} & 13.67 & 3.05 \\ \mathrm{e}_{\mathrm{ijf}} & 13.76 & 2.96 \\ \mathrm{E}_{\mathrm{j}} & 13.45 & 1.20 \\ \mathrm{e}_{\mathrm{ij}}{ }^{\mathrm{*}} \mathrm{E}_{\mathrm{j}} & 185.96 & 51.26 \\ \mathrm{E}_{\mathrm{j}} & 2.21 & 0.64\end{array}$

Years of education per worker: female

Years of education per workplace

Interaction own-workplace education

Dispersion of education per workplace

2.21

1.94

0.47

Log pay per hour

Log median wage per workplace

$\begin{array}{rrr}\mathrm{y}_{\mathrm{ij}} & 1.94 & 0.47 \\ \mathrm{Y}_{\mathrm{j}} & 9.55 & 0.32\end{array}$

Number of workers

$N_{i} \quad 18304$

Number of workplaces

$N_{j} \quad 1389$

Unweighted data. See Appendix Table 1 for definitions of variables, and for alternative derivations. ${ }^{\mathrm{a}} N_{j}=870$. 
Table 2

Log Pay Per Hour

Individual and Mean Workplace Education Levels

(GLS Random Effects)

\begin{tabular}{|c|c|c|c|}
\hline & \multicolumn{2}{|l|}{ MALE } & FEMALE \\
\hline & \multicolumn{2}{|l|}{ Coeff. (S.E.) } & Coeff. (S.E.) \\
\hline \multicolumn{4}{|l|}{$\operatorname{Model}[1]^{a}$} \\
\hline Firm-level characteristics & No & & No \\
\hline Own years of education $e_{i j}$ & $0.0600(0.0012)$ & $* * *$ & $0.0640(0.0014) * * *$ \\
\hline$?_{\mathrm{j}}$ & 0.3710 & & 0.3496 \\
\hline $\mathrm{R}^{2}$ total & 0.3919 & & 0.3662 \\
\hline \multicolumn{4}{|l|}{ Model $[2]^{a}$} \\
\hline Firm-level characteristics & Yes $^{b}$ & & Yes $^{b}$ \\
\hline Own years of education $e_{i j}$ & $0.0592(0.0012)$ & $* * *$ & $0.0635(0.0014) * * *$ \\
\hline$?_{\mathrm{j}}$ & 0.2833 & & 0.2437 \\
\hline $\mathrm{R}^{2}$ total & 0.4667 & & 0.4592 \\
\hline
\end{tabular}

\section{Model [3] ${ }^{a}$}

Firm-level characteristics

Own years of education $e_{i j}$

\begin{tabular}{ll}
\multicolumn{1}{c}{ Yes $^{\mathrm{b}}$} & \\
$0.0561(0.0012)$ & $* * *$ \\
$0.1084(0.0067)$ & $* * *$ \\
0.2543 & \\
0.5032 &
\end{tabular}

Yes $^{\mathrm{b}}$
$0.0614(0.0014) * * *$
$0.0740(0.0063) * * *$
0.2246
0.4787

\section{Model [4] ${ }^{a}$}

Firm-level characteristics

Own years of education $\mathrm{e}_{\mathrm{ij}}$

$\begin{array}{cc}\text { Yes }^{\mathrm{b}} & \\ 0.0983(0.0135) & * * * \\ 0.1530(0.0158) & * * * \\ -0.0031(0.0010) & * * * \\ 0.2517 & \\ 0.5045 & \end{array}$

Yes $^{\text {b }}$
$0.0523(0.0158) * * *$
$0.0651(0.0167) * * *$
$0.0007(0.0011)$
0.2232
0.4784

Mean workplace years of education $\mathrm{E}_{\mathrm{j}}$ Interaction $\mathrm{e}_{\mathrm{ij}} * \mathrm{E}_{\mathrm{j}}$

\begin{tabular}{lll}
$? \mathrm{j}$ & 0.2517 & 0.2232 \\
$\mathrm{R}^{2}$ total & 0.5045 & 0.4784 \\
\hline
\end{tabular}

$N_{j}\left[N_{i}\right]$

Unweighted data. Significance: $* * * 1 \%$ level; $* * 5 \%$ level; $* 10 \%$ level. Only full-time workers. $?_{\mathrm{j}}=\left(\sigma_{\mathrm{j}}\right)^{2} /\left[\left(\sigma_{\mathrm{j}}\right)^{2}+\left(\sigma_{\mathrm{i}}\right)^{2}\right]$

${ }^{a}$ Included set of individual haracteristics: tenure; tenure squared; age; age squared; ethnicity (1 dummy); disability (1); marital status (3); union member; temporary, fixed term or overtime worker (3).

${ }^{\mathrm{b}}$ Included set of firm-level characteristics are: industry sector (8); employment size; employment size squared; ratio part-time workers; share-ownership scheme (1); profit-related pay (1); workplace older than 20 years (1); labour proportions of operating costs (3); injury rate; and teamwork (1). 
Table 3

Log Pay Per Hour

Individual and Dispersion of Workplace Education Levels

(GLS Random Effects)

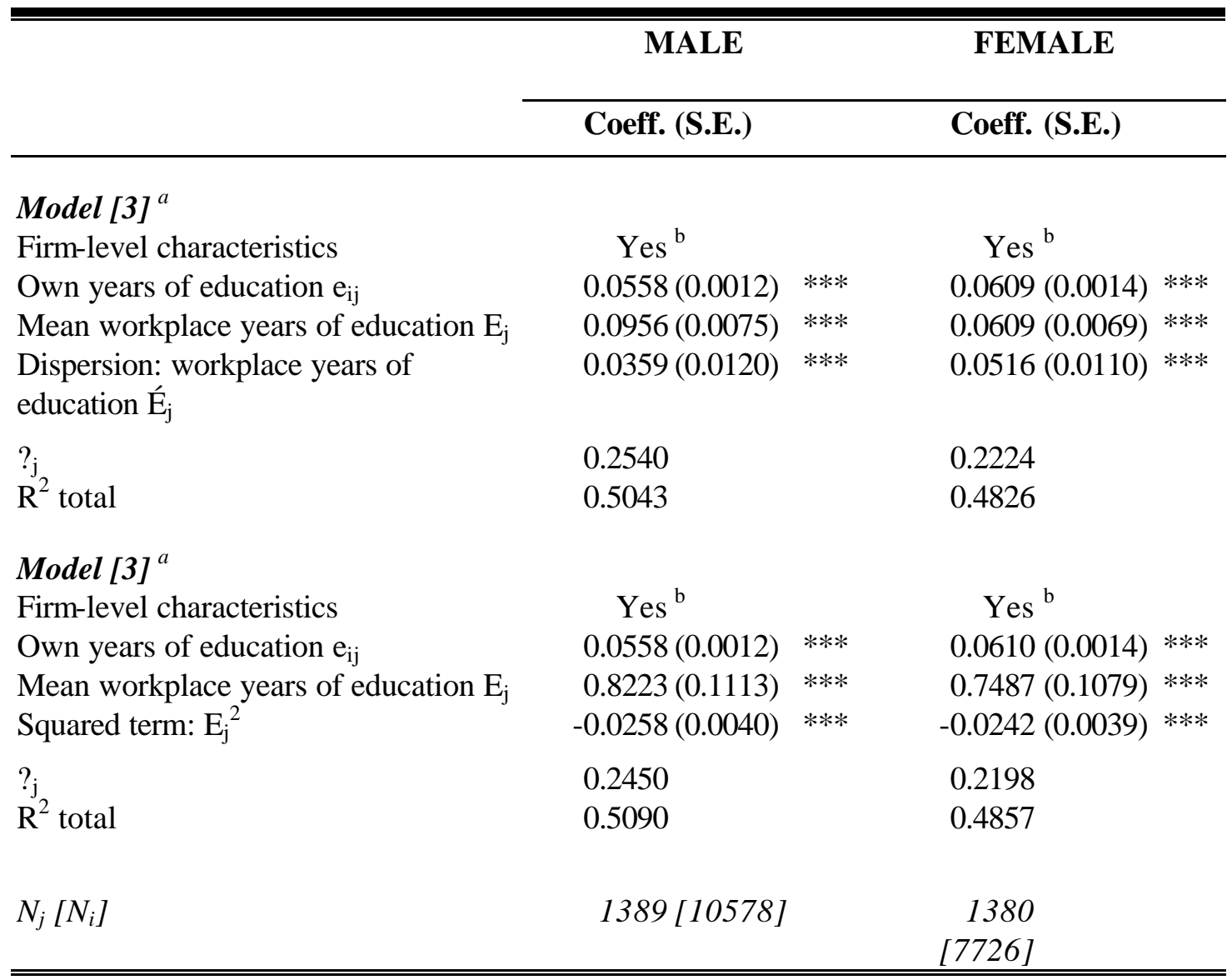

Unweighted data. Significance: $* * * 1 \%$ level; $* * 5 \%$ level; $* 10 \%$ level. Only full-time workers.

$?_{\mathrm{j}}=\left(\sigma_{\mathrm{j}}\right)^{2} /\left[\left(\sigma_{\mathrm{j}}\right)^{2}+\left(\sigma_{\mathrm{i}}\right)^{2}\right]$

${ }^{a}$ Included set of individual characteristics: tenure; tenure squared; age; age squared; ethnicity (1 dummy); disability (1); marital status (3); union member; temporary, fixed term or overtime worker (3).

${ }^{\mathrm{b}}$ Included set of firm-level characteristics are: industry sector (8); employment size; employment size squared; ratio part-time workers; share-ownership scheme (1); profit-related pay (1); workplace older than 20 years (1); labour proportions of operating costs (3); injury rate; and teamwork (1). 
Table 4

Log Pay Per Hour

Mean Workplace Education Levels for Union and Non-union Worker Sample

(GLS Random Effects)

\title{
MALE
}

FEMALE

\author{
Coeff. (S.E.) \\ Coeff. (S.E.)
}

Only union members:

\begin{tabular}{lllll}
\hline Years of education $\mathrm{e}_{\mathrm{ij}}$ & $0.0516(0.0017)$ & $* * *$ & $0.0622(0.0021)$ & $* * *$ \\
Mean workplace years of education $\mathrm{E}_{\mathrm{j}}$ & $0.0975(0.0087)$ & $* * *$ & $0.0551(0.0088)$ & $* * *$ \\
& 0.3095 & & 0.2668 \\
$?_{\mathrm{j}}$ & 0.4646 & 0.4485 & \\
$\mathrm{R}^{2}$ total & $0.0288(0.0181)$ & $0.1135(0.0244)$ & $* * *$ \\
\hline Years of education $\mathrm{e}_{\mathrm{ij}}$ & $0.0738(0.0207) * * *$ & $0.1053(0.0253)$ & $* * *$ \\
Mean workplace years of education $\mathrm{E}_{\mathrm{j}}$ & $0.0017(0.0013)$ & $-0.0036(0.0017)$ & $* *$ \\
Interaction $\mathrm{e}_{\mathrm{ij}} \mathrm{E}_{\mathrm{j}}$ & 0.3079 & 0.2610 & \\
$?_{\mathrm{j}}$ & 0.4638 & 0.4510 & \\
$\mathrm{R}^{2}$ total & $908[4888]$ & $809[3032]$ & \\
$N_{j}\left[N_{i}\right]$ & & &
\end{tabular}

Non-union members:

\begin{tabular}{|c|c|c|c|c|}
\hline Years of education $e_{i j}$ & $0.0591(0.0018)$ & $\begin{array}{l}* * * \\
* * *\end{array}$ & $0.0590(0.0018)$ & \\
\hline $\begin{array}{l}?_{\mathrm{j}} \\
\mathrm{R}^{2} \text { total }\end{array}$ & $\begin{array}{l}0.2283 \\
0.5365\end{array}$ & & $\begin{array}{l}0.2514 \\
0.4722\end{array}$ & \\
\hline $\begin{array}{l}\text { Years of education } e_{i j} \\
\text { Mean workplace years of education } E_{j} \\
\text { Interaction } e_{i j} * E_{j}\end{array}$ & $\begin{array}{r}0.1515(0.0198) \\
0.2113(0.0228) \\
-0.0069(0.0015)\end{array}$ & $\begin{array}{l}* * * \\
* * * \\
* * *\end{array}$ & $\begin{array}{l}0.0135(0.0213) \\
0.0342(0.0223) \\
0.0033(0.0015)\end{array}$ & $* *$ \\
\hline $\begin{array}{l}? \mathrm{j}_{\mathrm{j}} \\
\mathrm{R}^{2} \text { total } \\
N_{j}\left[N_{i}\right]\end{array}$ & $\begin{array}{l}0.2359 \\
0.5365 \\
1156[5690]\end{array}$ & & $\begin{array}{l}0.2531 \\
0.4715 \\
1203[4694]\end{array}$ & \\
\hline
\end{tabular}

Unweighted data. $\quad$ Significance: $* * * 1 \%$ level; $* * 5 \%$ level; $* 10 \%$ level.

Each estimation includes individuatlevel and firm-level characteristics, as per Models [3] and [4] of Table 2. See Notes to Table 2. 
Table 5

Log Pay Per Hour

Mean Workplace Education Levels for Restricted Sample

(GLS Random Effects)

MALE

FEMALE

Coeff. (S.E.)

Coeff. (S.E.)

Only firms working in teams:

\begin{tabular}{lllll}
\hline Own years of education $\mathrm{e}_{\mathrm{ij}}$ & $0.0542(0.0015)$ & $* * *$ & $0.0617(0.0016)$ & $* * *$ \\
Mean workplace years of education $\mathrm{E}_{\mathrm{j}}$ & $0.0926(0.0077)$ & $* * *$ & $0.0665(0.0071)$ & $* * *$ \\
$?_{\mathrm{j}}$ & 0.2468 & & 0.2178 \\
$\mathrm{R}^{2}$ total & 0.4942 & & 0.4636 & \\
\hline Own years of education $\mathrm{e}_{\mathrm{ij}}$ & $0.0925(0.0159)$ & $* * *$ & $0.0514(0.0181)$ & $* * *$ \\
Mean workplace years of education $\mathrm{E}_{\mathrm{j}}$ & $0.1328(0.0183)$ & $* * *$ & $0.0564(0.0191)$ & $* * *$ \\
Interaction $_{\mathrm{ij}} \mathrm{E}_{\mathrm{j}}$ & $-0.0028(0.0012)$ & $* *$ & $0.0007(0.0013)$ & \\
$?_{\mathrm{j}}$ & 0.2438 & & 0.2166 \\
$\mathrm{R}^{2}$ total & 0.4957 & 0.4633 \\
$N_{j}\left[N_{i}\right]$ & $976[7153]$ & $982[5859]$ & \\
\hline
\end{tabular}

Only labour-intensive firms:

\begin{tabular}{lllll}
\hline Own years of education $\mathrm{e}_{\mathrm{ij}}$ & $0.0528(0.0018)$ & $* * *$ & $0.0636(0.0017)$ & $* * *$ \\
Mean workplace years of education $\mathrm{E}_{\mathrm{j}}$ & $0.0987(0.0089)$ & $* * *$ & $0.0590(0.0078)$ & $* * *$ \\
$?_{\mathrm{j}}$ & 0.2582 & & 0.2112 & \\
R-squared total & 0.4893 & & 0.4546 & \\
\hline Own years of education $\mathrm{e}_{\mathrm{ij}}$ & $0.0708(0.0200)$ & $* * *$ & $0.0780(0.0215)$ & $* * *$ \\
Mean workplace years of education $\mathrm{E}_{\mathrm{j}}$ & $0.1170(0.0221)$ & $* * *$ & $0.0730(0.022)$ & $* * *$ \\
Interaction $\mathrm{e}_{\mathrm{ij}} \mathrm{E}_{\mathrm{j}}$ & $-0.0013(0.0014)$ & & $-0.0010(0.0015)$ & \\
$?_{\mathrm{j}}$ & 0.2493 & & 0.2071 \\
$\mathrm{R}^{2}$ total & 0.4901 & 0.4551 & \\
$N_{j}\left[N_{i}\right]$ & $701[4863]$ & $711[4449]$ &
\end{tabular}

Unweighted data. $\quad$ Significance: $* * * 1 \%$ level; $* * 5 \%$ level; $* 10 \%$ level.

Each estimation includes individuatlevel and firm-level characteristics, as per Models [3] and [4] of Table 2. See Notes to Table 2. 
Table 6

Log Median Wage of Workplace: Mean and Dispersion of Workplace Years of Education (OLS)

\begin{tabular}{|c|c|c|c|c|}
\hline & Model [A] & & Model [B] & \\
\hline & Coeff. (S.E.) & & Coeff. (S.E.) & \\
\hline Quit rate & $-0.1039(0.0411)$ & $* *$ & $-0.1130(0.0448)$ & $* *$ \\
\hline Absenteeism rate & $-0.0052(0.0017)$ & $* * *$ & $-0.0088(0.0019)$ & $* * *$ \\
\hline Union workplace & $0.0860(0.0187)$ & $* * *$ & $0.0911(0.0204)$ & $* * *$ \\
\hline International market competition & $0.0317(0.0188)$ & $*$ & $0.0326(0.0205)$ & \\
\hline Firm aged over 20 years & $0.0217(0.0152)$ & & $0.0111(0.0165)$ & \\
\hline Financial participation schemes & $-0.0122(0.0189)$ & & $-0.0348(0.0204)$ & $*$ \\
\hline Workplace size $<50$ & $0.0348(0.0266)$ & & $0.0162(0.0290)$ & \\
\hline Workplace size $50-100$ & $0.0036(0.0273)$ & & $0.0030(0.0297)$ & \\
\hline Workplace size $100-499$ & $0.0161(0.0279)$ & & $-0.0117(0.0303)$ & \\
\hline Workplace size 500-999 & $-0.0262(0.0316)$ & & $-0.0355(0.0345)$ & \\
\hline Workplace size 1000-3999 & $0.0202(0.0366)$ & & $0.0170(0.0399)$ & \\
\hline Workplace size 4000> & $-0.0635(0.0442)$ & & $-0.0319(0.0480)$ & \\
\hline Employment growth in last year & $0.0189(0.0147)$ & & $0.0154(0.0160)$ & \\
\hline Good relations: workers-management & $0.0136(0.0155)$ & & $0.0114(0.0372)$ & \\
\hline UK ownership in private sector & $-0.0650(0.0185)$ & $* * *$ & $-0.0871(0.0201)$ & $* * *$ \\
\hline Single firm & $-0.0249(0.0189)$ & & $-0.0343(0.0205)$ & $*$ \\
\hline$\%$ part-time workers & $-0.0115(0.0412)$ & & $-0.0841(0.0445)$ & $*$ \\
\hline$\%$ female workers & $-0.4497(0.0400)$ & $* * *$ & $-0.4364(0.0436)$ & $* * *$ \\
\hline$>80 \%$ fixed workers & $-0.0754(0.0512)$ & & $-0.0247(0.0557)$ & \\
\hline Any freelance workers & $0.0567(0.0206)$ & $* * *$ & $0.0640(0.0224)$ & $* * *$ \\
\hline Any shift work & $-0.0214(0.0165)$ & & $-0.0614(0.0178)$ & $* * *$ \\
\hline Fewer than 5 competitors & $0.0378(0.0157)$ & $* *$ & $0.0296(0.0171)$ & $*$ \\
\hline Mean workplace years & & & & \\
\hline Of education $\mathrm{E}_{\mathrm{j}}$ & $0.1297(0.0081)$ & $* * *$ & -- & \\
\hline $\begin{array}{l}\text { Dispersion of workplace years of } \\
\text { education } \hat{E}_{j}\end{array}$ & -- & & $0.0223(0.0024)$ & $* * *$ \\
\hline $\mathrm{R}$ squared & 0.5840 & & 0.5067 & \\
\hline Chi-squared & 29.37 & & 21.76 & \\
\hline$N$ & 870 & & 870 & \\
\hline
\end{tabular}


Variable and Method of Calculation

\section{Variables Used in Estimations:}

$\mathrm{e}_{\mathrm{ij}} \quad$ Worker years of education: converted from level of qualifications of: no qualifications (10 years); CSE/GCE/O-level (11); A-level (13); degree (16); higher degree (18). For those with additional vocational qualifications, one extra year was added.

$\mathrm{E}_{\mathrm{j}} \quad$ Mean workplace years of education: based on percentage of the workforce in each of $\mathrm{k}$ occupations times average years of education for that occupation from worker respondents $\left(\% \mathrm{OCC}_{\mathrm{jk}}\right) *\left(\mathrm{Se}_{\mathrm{ijk}} / \mathrm{n}_{\mathrm{k}}\right) \quad k=1 \ldots 9$

$\mathrm{E}_{\mathrm{j}} \quad$ Dispersion of workplace years of education: absolute mean diff. across workers based on $\mathrm{E}_{\mathrm{i}}$ $\mathrm{S} \mid\left(\mathrm{E}_{\mathrm{j}}-\mathrm{e}_{\mathrm{ij}}\right) / \mathrm{n}_{\mathrm{j}}$

$\mathrm{y}_{\mathrm{ij}} \quad$ Log pay per hour $\operatorname{Ln}\{($ Median pay of $k$ bands)/(no. of hours worked) $\}, k=1, . .12$

$\mathrm{Y}_{\mathrm{j}} \quad$ Log median wage at workplace Median of $\mathrm{y} 2_{\mathrm{j}}, \mathrm{j}=1 \ldots 870$

Substitute Variables for Sensitivity Analysis [Mean, Standard Deviation]:

E2 $2_{j} \quad$ Mean workplace years of education: based on mean of $\mathrm{e}_{\mathrm{ij}}$ across workplace
$\mathrm{S}\left(\mathrm{e}_{\mathrm{ij}}\right) / \mathrm{N}_{\mathrm{j}}$
[13.57, 1.68]

E3 3 Mean workplace years of education: based on percentage of the workforce in each of $k$ occupations times average years of education for that occupation from 1998 Labour Force Survey, split by gender

$\left(\% \mathrm{OCC}_{\mathrm{jk}}\right) *\left(\mathrm{Se}_{\mathrm{LFSkm}} / \mathrm{n}_{\mathrm{LFSkm}}\right) \quad k=1 \ldots 9, m=$ male, female

[17.32, 1.09]

É2 Dispersion of workplace years of education: absolute mean diff. across workers based on E2 $2_{\mathrm{i}}$ $\mathrm{S}\left|\mathrm{E} 2_{\mathrm{j}}-\mathrm{e}_{\mathrm{ij}}\right| \mathrm{n}_{\mathrm{j}} \quad$ [1.97, 0.64]

É $3_{\mathrm{j}} \quad$ Dispersion of workplace years of education: absolute mean diff. across workers based on E3 ${ }_{\mathrm{i}}$
$\mathrm{S}\left|\mathrm{E} 3_{\mathrm{j}}-\mathrm{e}_{\mathrm{ij}}\right| \mathrm{n}_{\mathrm{j}}$
$[4.02,1.07]$

Ésq $_{j} \quad$ Dispersion of workplace years of education: mean diff. across workers based on $\mathrm{E}_{\mathrm{i}}$ $\mathrm{S}\left(\mathrm{E}_{\mathrm{j}}-\mathrm{e}_{\mathrm{ij}}\right)^{2} / \mathrm{n}_{\mathrm{j}}$
[7.19, 3,57]

Ésq2 Dispersion of workplace years of education: mean diff. across workers based on $E 2_{\mathrm{i}}$ $\mathrm{S}\left(\mathrm{E} 2_{\mathrm{j}}-\mathrm{e}_{\mathrm{ij}}\right)^{2} / \mathrm{n}_{\mathrm{j}}$

$[6.07,3.11]$

Ésq $3_{j}$ Dispersion of workplace years of education: mean diff. across workers based on $E 3_{i}$ $\mathrm{S}\left(\mathrm{E} 3_{\mathrm{j}}-\mathrm{e}_{\mathrm{ij}}\right)^{2} / \mathrm{n}_{\mathrm{j}}$

$\mathrm{y} 2_{\mathrm{ij}} \quad$ Log annual earnings, using only 12 bands $\operatorname{Ln}\{$ Median pay of $k$ bands $\}, k=1, . .12$

$[9.88,0.45]$

See also Table 1. 


\begin{tabular}{|c|c|c|}
\hline Variable & Mean & S.D. \\
\hline \multicolumn{3}{|l|}{ Selected worker characteristics: } \\
\hline Tenure (years) & 7.02 & 5.49 \\
\hline Union member & 0.43 & 0.49 \\
\hline$N_{i}$ & 1830 & \\
\hline \multicolumn{3}{|l|}{ Firm-level Variables: } \\
\hline Quit rate & 0.15 & 0.20 \\
\hline Absenteeism rate & 4.39 & 4.13 \\
\hline Union workplace & 0.66 & 0.48 \\
\hline International market competition & 0.37 & 0.48 \\
\hline Firm aged over 20 years & 0.37 & 0.48 \\
\hline Financial participation schemes & 0.58 & 0.49 \\
\hline workplace size $<50$ & 0.28 & 0.45 \\
\hline workplace size $50-100$ & 0.14 & 0.35 \\
\hline workplace size 100-499 & 0.07 & 0.26 \\
\hline workplace size 500-999 & 0.03 & 0.16 \\
\hline workplace size 1000-3999 & 0.01 & 0.10 \\
\hline workplace size 4000> & 0.00 & 0.07 \\
\hline Employment growth in last year & 0.47 & 0.50 \\
\hline Good relations: workers-management & 0.32 & 0.46 \\
\hline UK ownership in private sector & 0.63 & 0.48 \\
\hline Single firm & 0.23 & 0.42 \\
\hline$\%$ part-time workers & 0.26 & 0.27 \\
\hline$\%$ female workers & 0.49 & 0.29 \\
\hline$>80 \%$ fixed workers & 0.02 & 0.14 \\
\hline Any freelance workers & 0.16 & 0.37 \\
\hline Any shift work & 0.50 & 0.50 \\
\hline Fewer than 5 competitors & 0.51 & 0.50 \\
\hline$N_{j}$ & 937 & \\
\hline
\end{tabular}




\section{IZA Discussion Papers}

\begin{tabular}{|c|c|c|c|c|}
\hline No. & Author(s) & Title & Area & Date \\
\hline 390 & T. Beissinger & $\begin{array}{l}\text { The Impact of Labor Market Reforms on Capital } \\
\text { Flows, Wages and Unemployment }\end{array}$ & 2 & $11 / 01$ \\
\hline 391 & $\begin{array}{l}\text { J. T. Addison } \\
\text { P. Teixeira }\end{array}$ & $\begin{array}{l}\text { Employment Adjustment in Portugal: Evidence } \\
\text { from Aggregate and Firm Data }\end{array}$ & 1 & $11 / 01$ \\
\hline 392 & $\begin{array}{l}\text { P. Tsakloglou } \\
\text { F. Papadopoulos }\end{array}$ & $\begin{array}{l}\text { Identifying Population Groups at High Risk of } \\
\text { Social Exclusion: Evidence from the ECHP }\end{array}$ & 3 & $11 / 01$ \\
\hline 393 & S. M. Fuess, Jr. & Union Bargaining Power: A View from Japan & 2 & $11 / 01$ \\
\hline 394 & $\begin{array}{l}\text { H. Gersbach } \\
\text { A. Schniewind }\end{array}$ & $\begin{array}{l}\text { Awareness of General Equilibrium Effects and } \\
\text { Unemployment }\end{array}$ & 2 & $11 / 01$ \\
\hline 395 & $\begin{array}{l}\text { P. Manzini } \\
\text { C. Ponsatí }\end{array}$ & Stakeholders, Bargaining and Strikes & 6 & $11 / 01$ \\
\hline 396 & $\begin{array}{l}\text { M. A. Shields } \\
\text { S. Wheatley Price }\end{array}$ & $\begin{array}{l}\text { Exploring the Economic and Social } \\
\text { Determinants of Psychological and Psychosocial } \\
\text { Health }\end{array}$ & 5 & $11 / 01$ \\
\hline 397 & $\begin{array}{l}\text { M. Frondel } \\
\text { C. M. Schmidt }\end{array}$ & $\begin{array}{l}\text { Evaluating Environmental Programs: The } \\
\text { Perspective of Modern Evaluation Research }\end{array}$ & 6 & $11 / 01$ \\
\hline 398 & $\begin{array}{l}\text { M. Lindeboom } \\
\text { F. Portrait } \\
\text { G. J. van den Berg }\end{array}$ & $\begin{array}{l}\text { An Econometric Analysis of the Mental-Health } \\
\text { Effects of Major Events in the Life of Elderly } \\
\text { Individuals }\end{array}$ & 5 & $11 / 01$ \\
\hline 399 & $\begin{array}{l}\text { J. W. Albrecht } \\
\text { J. C. van Ours }\end{array}$ & $\begin{array}{l}\text { Using Employer Hiring Behavior to Test the } \\
\text { Educational Signaling Hypothesis }\end{array}$ & 1 & $11 / 01$ \\
\hline 400 & R. Euwals & $\begin{array}{l}\text { The Predictive Value of Subjective Labour } \\
\text { Supply Data: A Dynamic Panel Data Model with } \\
\text { Measurement Error }\end{array}$ & 5 & $11 / 01$ \\
\hline 401 & $\begin{array}{l}\text { J. Boone } \\
\text { P. Fredriksson } \\
\text { B. Holmlund } \\
\text { J. C. van Ours }\end{array}$ & $\begin{array}{l}\text { Optimal Unemployment Insurance with } \\
\text { Monitoring and Sanctions }\end{array}$ & 3 & $11 / 01$ \\
\hline 402 & $\begin{array}{l}\text { O. Ashenfelter } \\
\text { D. Card }\end{array}$ & $\begin{array}{l}\text { Did the Elimination of Mandatory Retirement } \\
\text { Affect Faculty Retirement Flows? }\end{array}$ & 5 & $11 / 01$ \\
\hline 403 & L. Ljungqvist & How Do Layoff Costs Affect Employment? & 1 & $11 / 01$ \\
\hline 404 & $\begin{array}{l}\text { H. Battu } \\
\text { C. R. Belfield } \\
\text { P. J. Sloane }\end{array}$ & Human Capital Spill-Overs Within the Workplace & 1 & $11 / 01$ \\
\hline
\end{tabular}

